\title{
АНАЛІЗ ДЕПОЗИТНОЇ ПОЛІТИКИ КОМЕРЦІЙНИХ БАНКІВ УКРАЇНИ В УМОВАХ ЕКОНОМІЧНОЇ НЕСТАБІЛЬНОСТІ
}

\begin{abstract}
Анотація. У статті досліджено депозитну політику банківських установ в умовах економічної нестабільності в період з 2017 по 2020 роки. Проаналізовано основні показники макроекономічного впливу, такі як ВВП та індекс інфляції, визначена їхня роль у структурі депозитної політики банків. Проведено порівняння та співвідношення частки депозитних та кредитних ресурсів у складі ресурсної бази вітчизняних банків. Проведено дослідження обсягів забезпечення депозитними та кредитними ресурсами банківських установ України. Установлено, що кредитна діяльність банків в період економічної нестабільності в більшій мірі забезпечується за рахунок депозитних ресурсів. Визначено, що кожен із обраних показників так чи іначе несе за собою позитивний чи негативний вплив на подальший розвиток депозитної політики комерційних банків. Виявлені та проаналізовані сучасні тенденції росту депозитного забезпечення вітчизняних комерційних банків в порівнянні з минулими роками. Досліджені можливі наслідки втрати довіри населення до комерційних вітчизняних банків, проаналізована загальна кількість вкладів як фрізичних так і юридичних осіб.
\end{abstract}

Ключові слова: депозитна політика, депозитні ресурси, економічна нестабільність, комерційні банки.

Petyk Lyubov, Barabash Vladyslav Ivan Franko National University of Lviv

\section{ANALYSIS OF DEPOSIT POLICY OF COMMERCIAL BANKS OF UKRAINE IN CONDITIONS OF ECONOMIC INSTABILITY}

Summary. The current status of deposit policy of banking institutions in conditions of economic instability in the period from 2017 to 2020 has been analyzed in the article. The main indicators of macroeconomic impact, such as GDP, inflation index and their role in the structure of banks deposit policy have been determined. It was determined that GDP growth has a positive effect on the state of deposit policy of domestic banks, which allows the population to attract their free funds in larger amounts. Exceeding the growth rate of deposit resources over the growth rate of GDP has been determined. It was found that the decrease in inflation is positive in relation to the growth of deposit resources of banking institutions. The share of deposit and credit resources in the resource base of domestic banks have been compared. The volumes of provision of deposit and credit resources have been analyzed on the example of Ukrainian banks. It is established that the lending activity of banks in the period of economic instability is largely provided by deposit resources. The composition and changes in the structure of deposit resources in terms of sectors of the economy, the timing of the placement of these deposit resources, the type of depositors have been considered. Failure of credit policy of commercial banks in the period selected for the study has been determined. It is established that the lending activity of banks in the period of economic instability is largely provided by deposit resources. It is determined that each of the selected indicators in one way or another has a positive or negative impact on the further development of the deposit policy of commercial banks. The current growth trends of deposit provision of domestic commercial banks in comparison with previous years has been analyzed. The possible consequences of the loss of public confidence in commercial domestic banks has been considered. The total number of deposits of individuals and legal entities have been analyzed. The reason for the quantitative decline of some indicators in 2020 has been identified, namely the outbreak of the coronavirus pandemic in the world and attempts the state to contain inflation by the government.

Keywords: deposit policy, deposit resources, economic instability, commercial banks.

$\Pi$ остановка проблеми. Банківські установи відіграють одну 3 ключових ролей і нерозривно пов'язані з економічним становищем країни. Досвід останніх років вказує на те, що порушення функціонування банківської системи неодмінно призводить до макроекономічних проблем. 3 іншої сторони банківська система активно реагує на зворушення зі сторони макроекономічних чинників. Залучені кошти складають основну частину банківських ресурсів, частка яких в середньому складає 80\%. Тому важливо розглянути їхню взаємодію з внутрішніми та зовнішніми чинниками та їх вплив на депозитну політику комерційних банків. Це допоможе краще адаптуватися та змінювати підхід до управління ресурсами при кризових ситуаціях.
Аналіз останніх досліджень і публікацій. Значний внесок у дослідження менеджменту фінансового та банківського сектору, а також певні питання у галузі депозитної політики комерційних банків та її оптимізації проаналізовані у роботах закордонних та вітчизняних вчених, зокрема: О. Бартош, В. Бобиль, О. Васюренко, О. Вовчак, О. Колодізєв, Г. Коробовой, Т. У. Коха, О. Лаврушина, Р. Міллер, А. Мороз, Д. Полфреман, П. С. Роуз, М. Савлук, Дж. Сінк мол., Г. Тосунян, В. Усоскін тощо.

Виділення не вирішених раніше частин загальної проблеми. Для повноцінного функціонування банківської системи в майбутньому важливим є моніторинг та аналіз актуальних даних щодо впливу макро- та мікропоказників на депозитну діяльність вітчизняних комерційних банків. 
Мета статті. Головною метою щіеї роботи є дослідження депозитної політики комерційних банків України в розрізі їхнього взаємозв'язку з факторами зовнішнього та внутрішнього впливу.

Виклад основного матеріалу. При економічній нестабільності одним 3 перших на себе приймає удар ресурсне забезпечення банківських установ, що проявляеться у відпливі ресурсів від клієнтської бази.

Оскільки депозитна активність е основним видом забезпечення банку важливим є дослідити та проаналізувати взаємозв'язок впливу макроекономічного стану країни на банківську системи, а саме на динаміку показників із залучення коштів і рівень успішності депозитної діяльності комерційних банків [1].

Для аналізу впливу макроекономічного стану на депозитне забезпечення комерційних банків ми виділим наступні чинники: валовий внутрішній продукт та темп інфляції.

Також, для повної картини будуть проаналізовані чинники, що певним чином зумовлені загальною економічною ситуацією: облікова ставка НБУ, динаміка розмірів кредитних ресурсів та структура депозитної діяльності у розрізі вкладників.

Проаналізувавши вплив макроекономічної ситуації в країні на рівень депозитного забезпечення банківських установ дасть змогу дослідити співвідношення валового внутрішнього продукту та мобілізованих депозитів (рисунок 1).

На основі проведеного дослідження можна сказати, що в розрізі обраних років спостерігаеться позитивна динаміка росту як депозитних ресурсів так і ВВП. що свідчить про розвиток депозитного ринку комерційних банківських установ та взаемозв' язок цих показників.

У 2020 році відносно 2017 року обсяг депозитних ресурсів зріс на 449286 млн. грн. або на $49,98 \%$, що вказуе на розвиток депозитної політики банківських установ.

Позитивною оцінкою депозитної діяльності у тому числі виступае перевищення темпів росту депозитних ресурсів над темпами росту ВВП, що зросло у 2020 році відносно 2017 року на 1211182 млн. грн. або на 40,60\%.

Такий стан вказуе на зростання обсягу депозитних коштів не тільки за рахунок приросту ВВП, але й за рахунок залучення накопичених «непрацюючих» заощаджень вкладників [2].

Також, у період досліджуваних років спостерігаеться не тільки кількісне зростання депозитних ресурсів, а й збільшення їх питомої ваги у складі ВВП (рисунок 2). Зокрема, у 2020 рощі відносно 2017 року вона збільшуеться на $27,38 \%$, що вказуе на позитивний розвиток економіки, оскільки така ситуація вказуе на зростання частки ВВП, що сприяе розвитку економіки.

Отже, можемо вказувати, що ВВП здійснюе прямий вплив на зміну обсягів депозитного забезпечення банків загалом. Оскільки зростання даного показника свідчить про збільшення забезпеченості населення та підприємств ресурсами, що уможливлюе не тільки існування схеми «доходи-поточне споживання», але можливість функціонування схеми: надходження - поточне споживання + заощадження» [3].

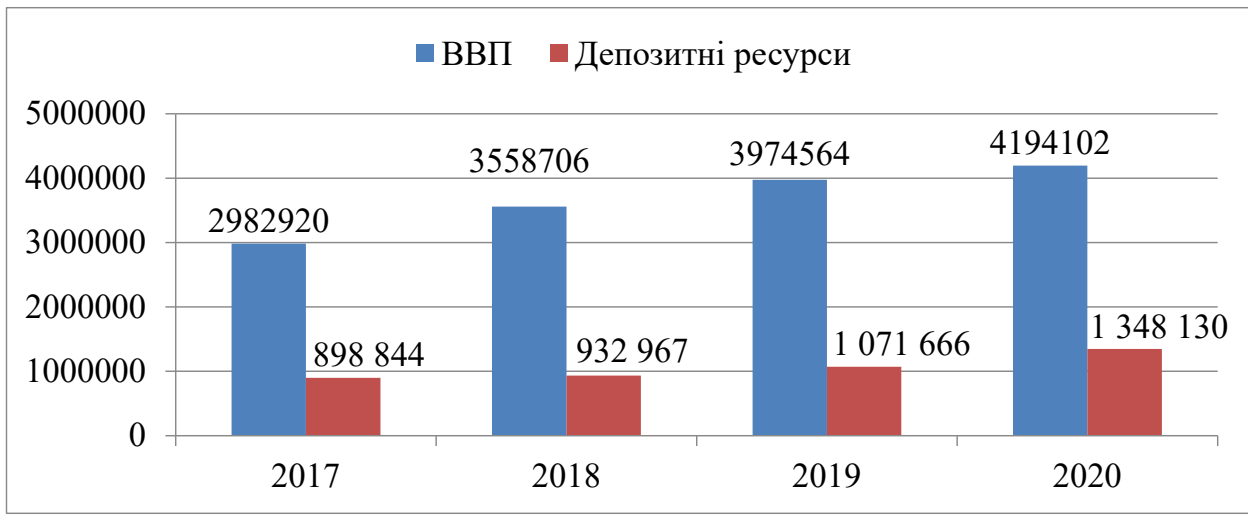

Рис. 1. Співвідношення депозитних ресурсів та ВВП

Джерело: розроблено авторами за даними [7]

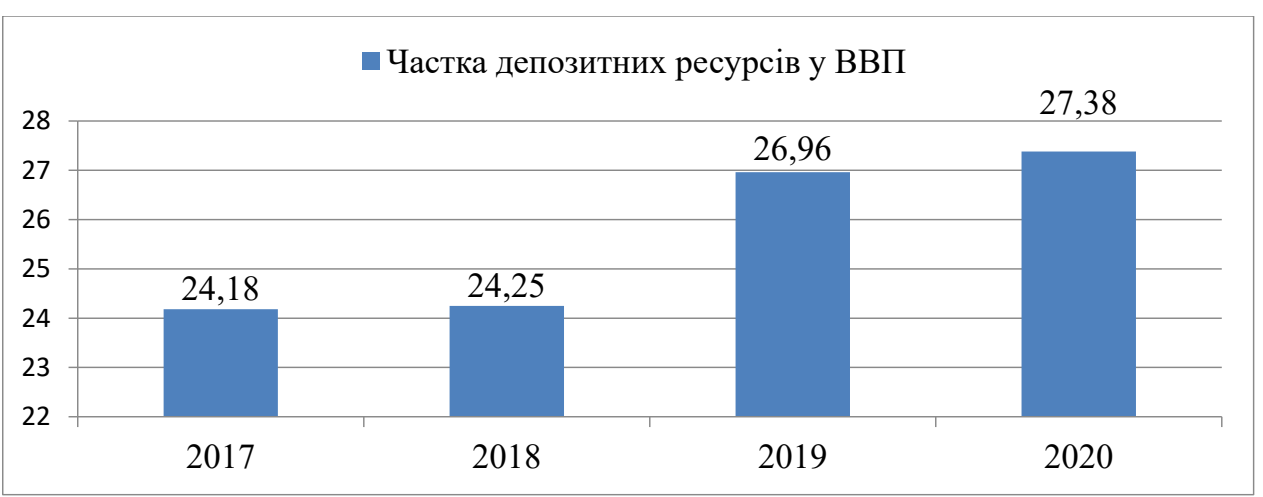

Рис. 2. Частка депозитних ресурсів у ВВП, \% 


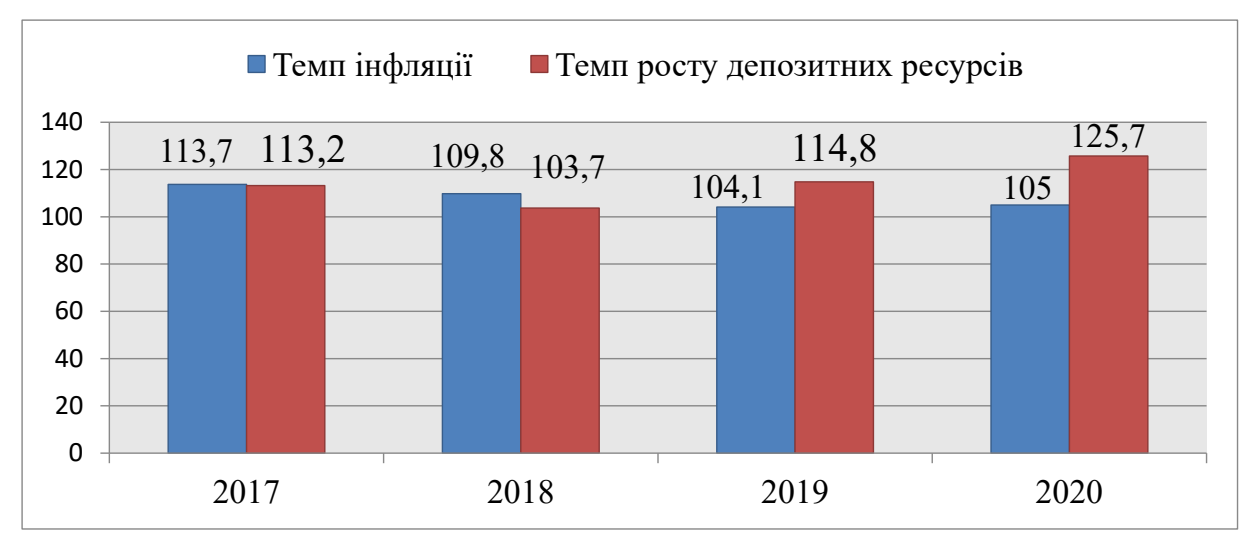

Рис. 3. Співвідношення темпів інфляції та темпу депозитних ресурсів, \%

Наступним розглянутим нами показником, що здійснюе вплив на депозитне забезпечення банків є рівень інфлящії, що підвищення росту якого діаметрально протилежно вливае на обсяги депозитних ресурсів в порівнянні з ВВП (рисунок 3). Оскільки його зростання спричиняе збільшення рівня цін, а, це в свою чергу викликае зростання витрат вкладників на поточні потреби та, відповідно, скорочення обсягів заощаджень [4].

Проаналізувавши дані 3 рисинку 3 можна припустити, що при знижені темпу інфляції спостерігаеться підвищення росту депозитних ресурсів. Протягом 2017-2018 років темп інфляції переважав, що мало негативний вплив на темпи росту депозитних ресурсів, але відбулось значне покращення у 2019 р. (різниця становила 10,1\%) у зв'язку з відновленням довіри населення до банків, в свою чергу припливом нових резервів 3 депозитних операцій.

Відповідно можемо вказувати на те, що у 2020 році темп інфлящії відносно 2017 року зменшився на $8,7 \%$, що зумовило позитивну динаміку темпів росту депозитної діяльності вітчизняних комерційних банків на $12,5 \%$ і свідчить про зворотній вплив стану банківської системи на макроекономічне становище країни загалом.

Також, важливими важелями впливу на депозитну політику комерційних банків виступають інструменти макрорегулятора НБУ .

Облікова ставка - один із монетарних інструментів, за допомогою якого Національний банк України встановлюе для банків та інших суб'єктів грошово-кредитного ринку оріентир щодо вартості залучених і розміщених грошових коштів на відповідний період [5].

Облікова ставка виступае базою для комерційних банків щодо встановлення цінової політики, а отже і депозитної (рисунок 4).

Проаналізувавши рисунок 4 можна побачити що вартість депозитів нижчаа в порівнянні з обліковою ставкою НБУ на протязі майже всього досліджуваного періоду, але пониження цього показника є результатом інших зовнішніх фракторів, таких як попит на кредитні ресурси зі сторони населення, а також попиту та пропозиції на депозитні ресурси загалом.

У 2015 році ми можемо спостерігати найбільшу впродовж досліджуваного періоду різницю між ставкою НБУ та вартістю депозитних коштів яка складала 8,6, що зумовлено зменшенням облікової ставки, а також зростанням пропозиції на ринку депозитних коштів [4].

Вже в 2016 р. в насідок макроекономічної стабілізації в країні облікова ставка НБУ знизилась на 8\%, а відповідно і знизилась вартість депозитних ресурсів.

Впродовж 2016-2019 рр. як облікова ставка так і вартість депозитних ресурсів будуть триматись на рівні і не виділятись великими відхиленнями.

3 метою утримання інфляції та загостреною ситуацією пов'язаною із пандемією коронавірусу в 2020 р., НБУ прийняло рішення про зниження

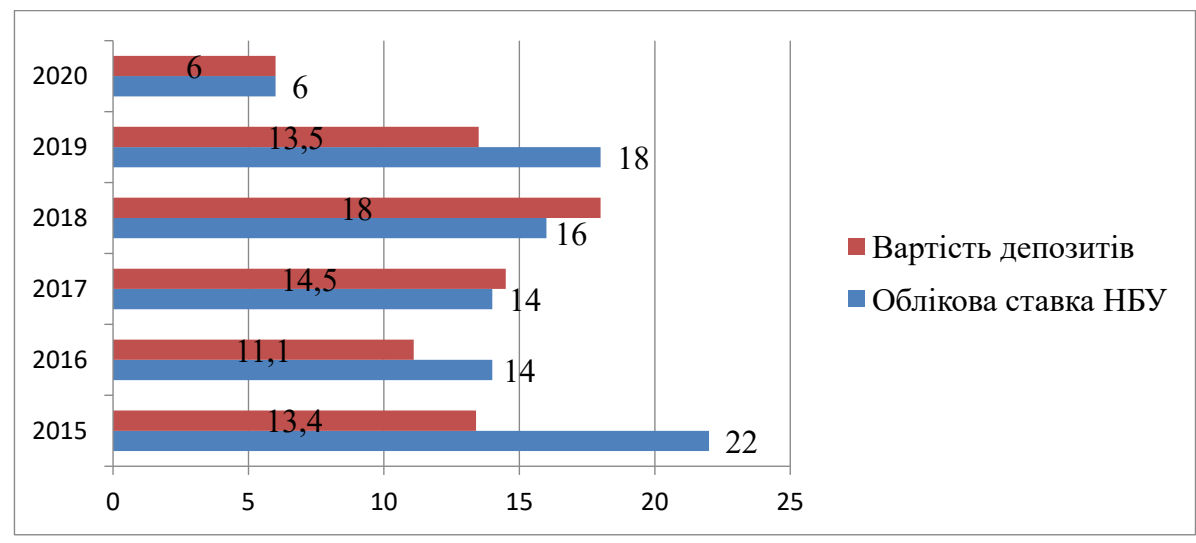

Рис. 4. Співвідношення облікової ставки НБУ та вартості депозитних ресурсів, \% 


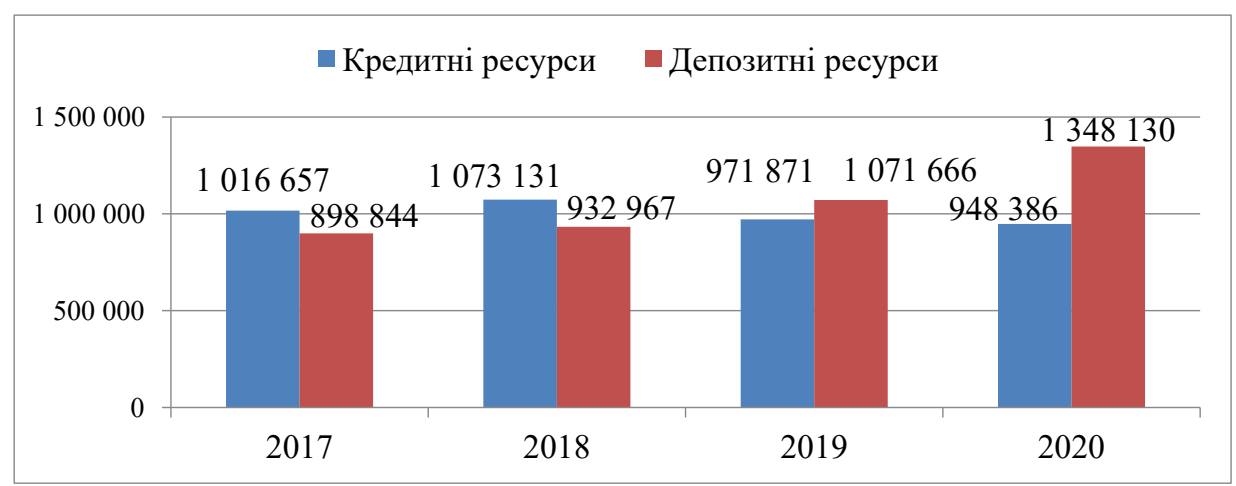

Рис. 5. Співвідношення кредитних та депозитних ресурсів у 2017-2020 рр., млн. грн.

Джерело: розроблено авторами за даними [7]

облікової ставки до 6\%, що є найнижчим показником за всю історію незалежної України, відповідно була знижена і вартість депозитних ресурсів яка вперше протягом досліджуваного періоду зрівнялася із ставкою НБУ.

Не менш важливим чинником, що впливає на динаміку депозитної політики є розмір кредитних ресурсів, що в свою чергу коригується за рахунок економічною ситуацією та стабільністю у країні (рисунок 5).

На основі рисунку 5, можна стверджувати що впродовж досліджуваного періоду ситуащія стосовно кількості кредитних та депозитних ресурсів дещо змінилась. Якщо впродовж 2017-2019 pp. спостерігалась домінація саме кредитних ресурсів то вже в 2019-2010 рр. депозитні ресурси зайняли їх місце. Особливо це помітно у 2020 р., коли різниця сягала $42.1 \%$, що свідчить про невдалу кредитну політику банків у цьому проміжку часу.

Якщо говорити про депозитну політику то вона однозначно є успішною (рис. 6), у 2020 р. частка депозитних джерел фрінансування кредитної діяльності сягала 134,81\%.

Станом на 2017 рік доля забезпечення складала 89,88\%, що дозволяє стверджувати, що протягом обраного періоду дослідження кредитна діяльність банків практично в повній мірі забезпечувалась за рахунок депозитних джерел, починаючи з 2019 (107,16\%) вона повністю перекривала їх фрінансування.
Проведемо дослідження в розрізі вкладників комерційних вітчизняних банків та визначем їхню частку, що допоможе охарактеризувати розвиток депозитної політики в ключі населення (рисунок 6). Також результати даного дослідження дадуть змогу визначити рівень довіри населення до банків загалом.

На основі рисунку можна зробити висновок, що в 2018-2019 рр. була зменшена кількість вкладів зі сторони населення країни, що свідчить про втрату його довіри до банківських установ.

Зменшення цього показника $е$ негативною характеристикою для депозитної політики та їі недостатній розвиток, так як частина населення зберігає свої заощадження у непрацюючій фрормі, що негативно впливаю на стан економіки країни загалом [8].

У 2020 р. ситуація покращилась, ми можемо спостерігати приріст вкладів зі сторони населення на 10,7\% в порівнянні з 2019 р., що позитивно вплинуло на загальний стан депозитної політики та її розвитку.

Віднова довіри населення до банків може виступати однією з причин покращення і інших показників розглянутих вище у це й ж період часу.

Висновки і пропозиції. У даній статті розглянуто вплив та зв'язок окремих макроекономічних та інших чинників на яких вони несуть вплив із показниками депозитної політики комерщійних банків України під час економічної нестабільності.

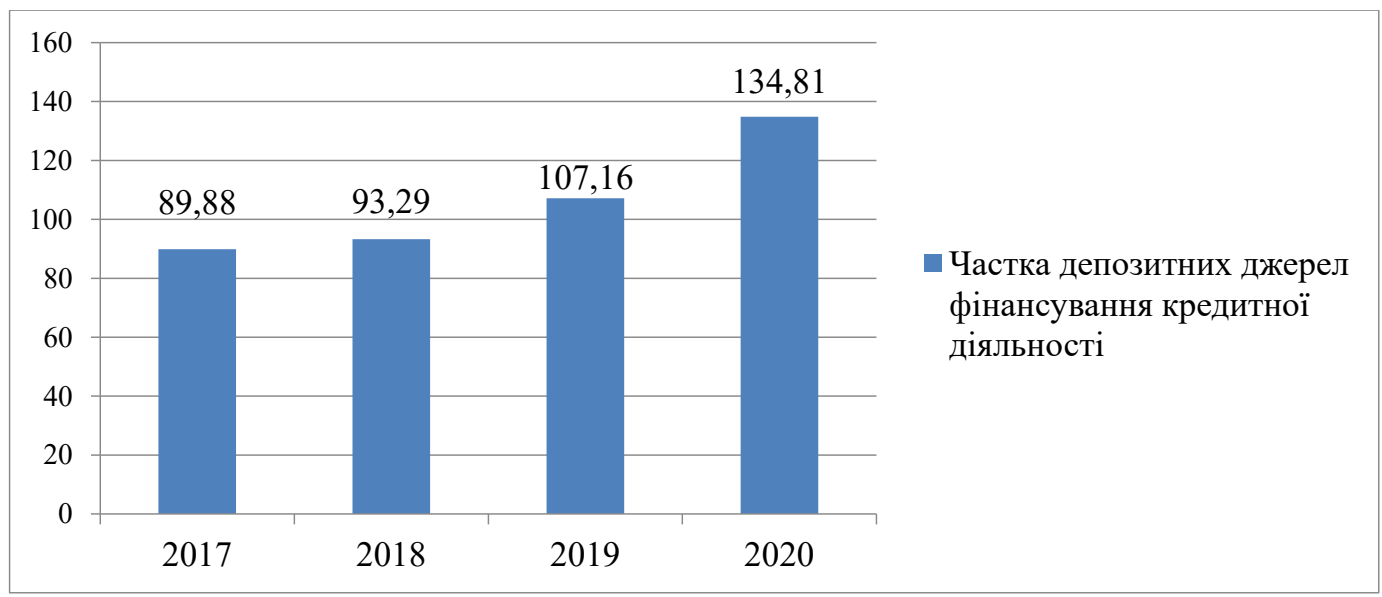

Рис. 6. Доля депозитних ресурсів у кредитних активах банківської системи у 2017-2020 роках, \% Джерело: розроблено авторами за даними [7] 


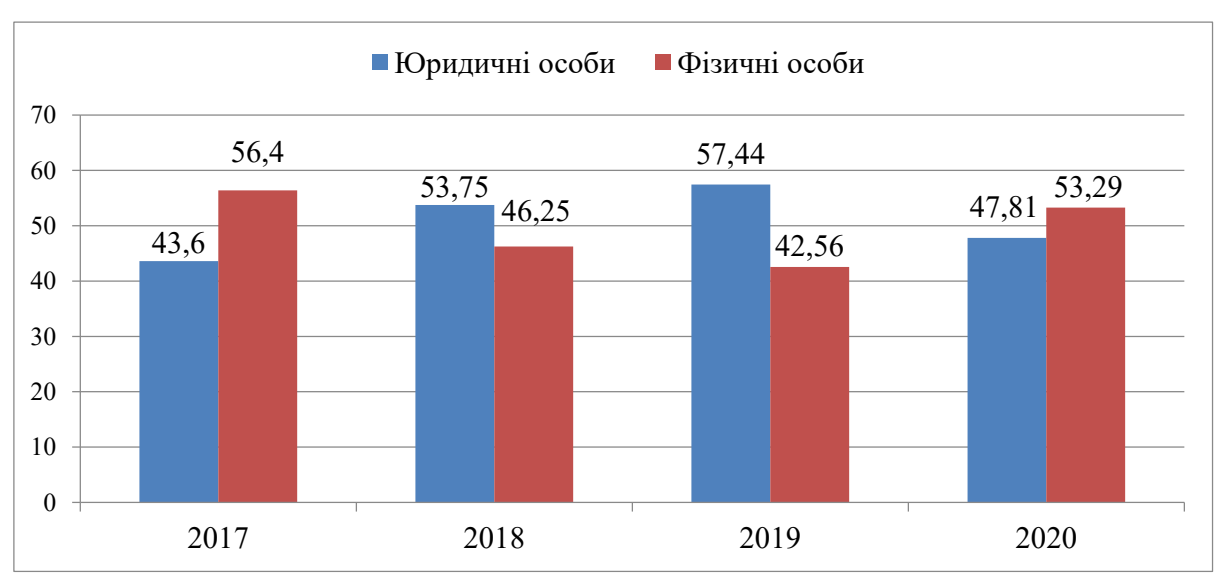

Рис. 7. Співвідношення депозитних вкладів юридичних та фізичних осіб у 2017-2020 рр., \% Джерело: розроблено авторами за даними [7]

Дослідивши та проаналізувавши динаміку змін цих показників в період 2017-2020 рр. можна припустити, що кожен з обраних показників несе позитивний чи негативний вплив на розвиток депозитної політики загалом. Ріст усіх обраних показників, окрім темпів розвитку інфляції мали позитивний характер для подальшого розвитку депозитної політики.

На основі проаналізованих показників співвідношення депозитних вкладів юридичних та фрізичних осіб можна зробити висновок, що рівень довіри населення країни $е$ важливим елементом фонкціонування банківської системи та збільшення його кількісного значення позитивно впливає на розвиток депозитної політики вітчизняних банків.

Також, необхідно виділити показники облікової ставки НБУ та вартості депозитних ресурсів які помітно зменшились у 2020 р. в порівнянні попередніми роками. Причиною цього послугував вспелск пандемії коронавірусу та утримання рівня інфрлящії. Результатом цього може стати падіння української економіки у більшому прояві від запланованого.

\section{Список літератури:}

1. Гарбар Ж.В. Особливості формування депозитного портфелю банківських установ. URL: http://intkonf.org/ kengarbar-zhv-malyasova-iv-osoblivosti-formuvannya-depozitnogo-portfelyubankivskih-ustanov

2. Герасимович А.М., Алексеенко М.Д., Парасій-Вергуненко I.М. Аналіз банківської діяльності : підручник. Київ : КНЕУ, 2010. 599 с.

3. Ісаева М.В. Формування напрямів удосконалення управління депозитними операціями банку на основі побудови «дерева цілей». URL: http://www.sworld.com.ua/konfer29/1282.pdf

4. Дзюблюк О.В. Банківські операції : підручник. Тернопіль : ТНЕУ «Економічна думка», 2013. 864 с.

5. Про Національний банк України : Закон України від 1999, № 29, ст. 238. Визначення терміна в редакції Закону № 2478-VI від 09.07.2010.

6. Національний банк України: грошово-кредитна статистика. URL: https://bank.gov.ua/ua/statistic/sectorfinancial/data-sector-financial

7. Національний банк України: облікова ставка Національного банку. URL: https://bank.gov.ua/ua/monetary/ stages/archive-rish

8. Косова Т.Д. Аналіз банківської діяльності : навч. пос. Київ : Центр учбової літератури, 2011. 486 с.

\section{References:}

1. Harbar Zh.V. Osoblyvosti formuvannia depozytnoho portfeliu bankivskykh ustanov [Features of the formation of the deposit portfolio of banking institutions]. Available at: http://intkonf.org/kengarbar-zhv-malyasova-ivosoblivosti-formuvannya-depozitnogo-portfelyubankivskih-ustanov

2. Herasymovych A.M., Alekseienko M.D., Parasii-Verhunenko I.M. (2010) Analiz bankivskoi diialnosti [Analysis of banking activities]. Kyiv: KNEU.

3. Isaieva M.V. Formuvannia napriamiv udoskonalennia upravlinnia depozytnymy operatsiiamy banku na osnovi pobudovy «dereva tsilei» [Formation areas to improve the management of the bank deposit operations by constructing the «tree of goals»]. Available at: http://www.sworld.com.ua/konfer29/1282.pdf

4. Dziubliuk O.V. (2013) Bankivski operatsii [Banking operations]. Ternopil: TNEU «Ekonomichna dumka».

5. Pro Natsionalnyi bank Ukrainy: Zakon Ukrainy vid 1999, № 29, st. 238. Vyznachennia termina v redaktsii Zakonu № 2478-VI vid 09.07.2010. Available at: https://bank.gov.ua/ua/monetary/stages/archive-rish

6. Natsionalnyi bank Ukrainy: hroshovo-kredytna statystyka [National Bank of Ukraine: monetary statistics]. Available at: https://bank.gov.ua/ua/statistic/sector-financial/data-sector-financial

7. Natsionalnyi bank Ukrainy: oblikova stavka Natsionalnoho banku [National Bank of Ukraine: discount rate of the National Bank]. Available at: https://bank.gov.ua/ua/monetary/stages/archive-rish

8. Kosova T.D. (2011) Analiz bankivskoi diialnosti [Analysis of banking activities]. Kyiv: Tsentr uchbovoi literatury. 